\title{
The Clinical Significance of the Extent of Positive Surgical Margins in Partial Nephrectomy performed for Renal Cell Carcinoma
}

\section{Ziting Wang ( $\nabla$ ziting_wang@nuhs.edu.sg )}

National University Hospital

Yi Quan Tan

National University Hospital

Jirong Lu

National University Hospital

Yen Seow Benjamin Goh

National University Hospital

Kep Yong Loh

Singapore General Hospital

Ho Yee Tiong

National University Hospital

\section{Research Article}

Keywords: Carcinoma, renal cell, nephrectomy, recurrence

Posted Date: April 15th, 2021

DOl: https://doi.org/10.21203/rs.3.rs-396480/v1

License: (c) (i) This work is licensed under a Creative Commons Attribution 4.0 International License.

Read Full License 


\section{Abstract}

\section{Purpose}

This study aims to review the occurrences of extensive positive surgical margins and focal positive surgical margins after partial nephrectomy for kidney cancer, comparing their associations and clinical outcomes with those with negative surgical margins.

Materials and Methods

Between 2014 to 2019, a total of 137 partial nephrectomies for cancer was performed. Pathological surgical margins were classified according to negative surgical margins $(n=156)$, extensive positive margins $(n=7)$, or focal positive surgical margins $(n=15)$. Peri-operative data, functional and oncological outcomes were compared among the three groups.

Results

Baseline clinical characteristics were comparable in all three groups except for gender, with a significantly greater proportion of male patients $(P=0.02)$ with extensive positive surgical margins and focal positive surgical margins than negative surgical margins. Negative surgical margins was associated with shorter operative time compared with extensive and focal positive surgical margins. Pathologically, perinephric fat invasion was significantly associated $(P<0.01)$ with positive surgical margins but there were no other differences in terms of cell type, grade and necrosis. There were a total of 4 local recurrences, all in the extensive positive surgical margins group with a median follow up period of 32.8 months.

\section{Conclusions}

Extensive positive surgical margins and focal positive surgical margins share similar peri-operative associations when compared with negative surgical margins but have different pathological and oncological implications to each other. The higher association of pathological T3a stage with extensive positive margins may account for the finding that local recurrences exclusively occur in patients with extensive positive surgical margins.

\section{Introduction}

In the last 3 decades, the incidence of renal cell carcinoma has doubled in developed countries ${ }^{1}$, especially with the rising use of cross-sectional imaging scans. With the use of these scans, incidental small renal masses are also detected more commonly. These renal masses are often amenable to nephron sparing surgery when they are discovered early. Van Poppel et $\mathrm{al}^{2}$ and the ensuing meta-analysis have demonstrated that overall renal function preservation was achieved better with partial nephrectomy than with radical nephrectomy. As such, there is an increasing emphasis to perform partial nephrectomy whenever surgically feasible. 
However, the same randomised trials and prospective studies also showed that partial nephrectomy is also accompanied by a higher complication rate and the concerns of local recurrences. Currently, clinical and pathological factors predicting for recurrence and progression after partial nephrectomy for localised renal cell carcinoma are relatively well defined. In addition, there is a paucity of data on the subject of surgical margins. As a result, there is a lack of guidance on the best strategy for follow up and intervention of such cases.

This study aims to review the occurrences of positive surgical margins (PSM) and focally positive surgical margins after partial nephrectomy for kidney cancer, comparing their associations and clinical outcomes with those with negative surgical margins (NSM).

\section{Materials And Methods}

The authors performed a retrospective review of 137 patients who underwent partial nephrectomy at a single institution between January 2014 to December 2019. The inclusion criteria was localised renal cell carcinoma (cT1-cT3). The partial nephrectomies were either performed in an open manner, or laparoscopically either with or without the assistance of a Da Vinci Si Surgical System (Intuitive Surgical, Sunnyvale, CA, USA). The study was approved by the local ethics committee, the Domain Specific Review Board of the National Healthcare group, Singapore. Data was collected on the patients' clinical demographics, pathological stage, grade, and surgical margin status. The extent of positive surgical margins were classified as focal, defined as a single margin with $5 \mathrm{~mm}$ involvement or less and extensive, defined as greater than $5 \mathrm{~mm}$. When multiple margins were involved, they were also considered as extensive margin involvement.

The patients were monitored until death or the last follow-up visit according to the surveillance protocol recommended by the European Association of Urology based on the UCLA Integrated Staging System for Renal Cell Carcinoma. Imaging was performed with computed tomography scans of the abdomen and pelvis together with a computed tomography scan of the chest or a chest radiography. When clinical recurrence was suspected, further evaluation of the possible metastases was performed with radionuclide bone scans or fluorodeoxyglucose (FDG)-positron emission tomography scans.

Pathological surgical margins were classified according to negative surgical margins ( $n=115$, extensive positive surgical margins $(n=7)$, or focal positive surgical margins $(n=15)$. data, functional and oncological outcomes were compared among the three groups.

\section{Statistical analysis}

We reported differences between categorical variables using the Chi-squared, Fisher's exact when more than $20 \%$ of cells have expected frequencies of less than 5 , and Krusker Wallis tests. Means were analysed using the One-Way Analysis of Variance (ANOVA) test. Statistical analysis was also performed using Kaplan-Meier survival curves. Statistical analyses were performed using the Stata STATA IC13.1 (StataCorp, 4905 Lakeway, College Station, TX, 77845, USA). 


\section{Results}

137 renal cell carcinoma patients underwent partial nephrectomy were included in the study. The clinical characteristics of the patients are detailed in Table 1. The mean follow-up was 32.8 months. Of these patients, 115 (83.9\%) were classified as negative surgical margins after the partial nephrectomy. 22 patient had positive surgical margins, of which 7 were categorised as extensive based on our predetermined definition, and 15 were focal positive margins. There was higher association of positive surgical margins with the male gender $(p=0.002) .60 .6 \%$ of patients were overweight based on the World Health Organisation classification of weight status. However, it should be noted that these are international classifications, and calculated cut off points may vary for our Asian population which often have lower mean and median body mass index BMI. There was no significant difference in median age or body mass index. There was also no difference in the anatomic complexity of the tumour, as measured by the RENAL nephrometry score, both in parts and sum. $25.5 \%$ of the tumours were termed as low in complexity, $31.4 \%$ were moderate, $43.1 \%$ were considered high in complexity. 
Table 1

Clinical demographics of the patients who underwent partial nephrectomy between January 2014 and December 2019

\begin{tabular}{|c|c|c|c|c|c|}
\hline Variable & $\begin{array}{l}\text { Overall } \\
N= \\
137\end{array}$ & $\begin{array}{l}\text { Negative } \\
\text { surgical } \\
\text { margins } \\
\mathrm{N}=115\end{array}$ & $\begin{array}{l}\text { Extensive positive } \\
\text { surgical margins } \\
\mathrm{N}=7\end{array}$ & $\begin{array}{l}\text { Focal positive } \\
\text { surgical } \\
\text { margins } \\
\mathrm{N}=15\end{array}$ & $\begin{array}{l}P \\
\text { value }\end{array}$ \\
\hline $\begin{array}{l}\text { Median Age at Surgery } \\
\text { (IQR) }\end{array}$ & $\begin{array}{l}58 \\
(51- \\
67)\end{array}$ & $58(50-67)$ & $66(54-69)$ & $60(53-68)$ & 0.62 \\
\hline Male Gender & $\begin{array}{l}97 \\
(70.8)\end{array}$ & $76(66.1)$ & $7(100.0)$ & $14(93.3)$ & 0.02 \\
\hline Body Mass Index & & & & & 0.92 \\
\hline 18.49 and below & $4(2.9)$ & $4(3.5)$ & $0(0.0)$ & $0(0.0)$ & \\
\hline 18.5 to 24.9 & $\begin{array}{l}50 \\
(36.5)\end{array}$ & 42 (36.5) & $2(28.6)$ & $6(40.0)$ & \\
\hline 25.0 to 29.9 & $\begin{array}{l}59 \\
(43.1)\end{array}$ & $50(43.5)$ & $3(42.9)$ & $6(40.0)$ & \\
\hline 30.0 and greater & $\begin{array}{l}24 \\
(17.5)\end{array}$ & $19(16.5)$ & $2(28.6)$ & $3(20.0)$ & \\
\hline RENAL Score & & & & & 0.43 \\
\hline $4-6$ & $\begin{array}{l}35 \\
(25.5)\end{array}$ & $33(28.7)$ & $2(28.6)$ & $0(0.0)$ & \\
\hline $7-9$ & $\begin{array}{l}43 \\
(31.4)\end{array}$ & $35(30.4)$ & $1(14.3)$ & $7(46.7)$ & \\
\hline $10-12$ & $\begin{array}{l}59 \\
(43.1)\end{array}$ & 47 (40.9) & $4(57.1)$ & $8(53.3)$ & \\
\hline RENAL Scoring: Radius & & & & & 0.93 \\
\hline 1 point & $\begin{array}{l}118 \\
(86.1)\end{array}$ & $99(86.1)$ & $5(71.4)$ & $14(93.3)$ & \\
\hline 2 points & $\begin{array}{l}19 \\
(13.9)\end{array}$ & $16(13.9)$ & $2(28.6)$ & $1(6.7)$ & \\
\hline 3 points & $0(0.0)$ & $0(0.0)$ & $0(0.0)$ & $0(0.0)$ & \\
\hline $\begin{array}{l}\text { RENAL Scoring: } \\
\text { Exophytic }\end{array}$ & & & & & 0.44 \\
\hline 1 point & $\begin{array}{l}27 \\
(19.7)\end{array}$ & $26(22.6)$ & $1(14.3)$ & $0(0.0)$ & \\
\hline
\end{tabular}




\begin{tabular}{|c|c|c|c|c|c|}
\hline Variable & $\begin{array}{l}\text { Overall } \\
N= \\
137\end{array}$ & $\begin{array}{l}\text { Negative } \\
\text { surgical } \\
\text { margins } \\
\mathrm{N}=115\end{array}$ & $\begin{array}{l}\text { Extensive positive } \\
\text { surgical margins } \\
\mathrm{N}=7\end{array}$ & $\begin{array}{l}\text { Focal positive } \\
\text { surgical } \\
\text { margins } \\
\mathrm{N}=15\end{array}$ & $\begin{array}{l}P \\
\text { value }\end{array}$ \\
\hline 2 points & $\begin{array}{l}79 \\
(57.7)\end{array}$ & $64(55.7)$ & $4(57.1)$ & $11(73.3)$ & \\
\hline 3 points & $\begin{array}{l}31 \\
(22.6)\end{array}$ & $25(21.7)$ & $2(28.6)$ & $4(26.7)$ & \\
\hline RENAL Scoring: Nearness & & & & & 0.30 \\
\hline 1 point & $\begin{array}{l}32 \\
(23.4)\end{array}$ & $31(27.0)$ & $0(0.0)$ & $1(6.3)$ & \\
\hline 2 points & $\begin{array}{l}17 \\
(12.4)\end{array}$ & $12(10.4)$ & $3(50.0)$ & $2(12.5)$ & \\
\hline 3 points & $\begin{array}{l}88 \\
(64.2)\end{array}$ & $72(62.6)$ & $3(50.0)$ & $13(81.2)$ & \\
\hline $\begin{array}{l}\text { RENAL Scoring: } \\
\text { Anterior/Posterior }\end{array}$ & & & & & 0.72 \\
\hline A & $\begin{array}{l}60 \\
(43.8)\end{array}$ & $53(46.1)$ & $2(28.6)$ & $5(33.3)$ & \\
\hline$P$ & $\begin{array}{l}45 \\
(32.8)\end{array}$ & 37 (32.2) & $2(28.6)$ & $6(40.0)$ & \\
\hline$x$ & $\begin{array}{l}32 \\
(23.4)\end{array}$ & $25(21.7)$ & $3(42.9)$ & $4(26.7)$ & \\
\hline $\begin{array}{l}\text { RENAL Scoring: Location } \\
\text { Relative to Polar Lines }\end{array}$ & & & & & 0.85 \\
\hline 1 point & $\begin{array}{l}40 \\
(29.2)\end{array}$ & $35(30.4)$ & $2(28.6)$ & $3(20.0)$ & \\
\hline 2 points & $\begin{array}{l}39 \\
(28.5)\end{array}$ & $31(27.0)$ & $4(57.1)$ & $4(26.7)$ & \\
\hline 3 points & $\begin{array}{l}58 \\
(42.3)\end{array}$ & $49(42.6)$ & $1(14.3)$ & $8(53.3)$ & \\
\hline
\end{tabular}

Operative data included approach of surgery, total operative time, warm ischemia time, estimated blood loss, length of hospitalisation and rates of major complication, as defined by Clavien-Dindo classification 3-5 (Table 2). $26.5 \%$ of the operations were carried out in the open approach and $18.1 \%$ were carried out laparoscopically without the help of the Da Vinci Surgical System. From 2014, the use of robotic surgery increased annually. During the same period, the use of both laparoscopic and open surgery declined. Oneway analysis of variance tests were conducted if operative parameters were significantly different for the groups. There was no statistical difference for warm ischemia time, estimated blood loss, length of stay 
or complications. However, we noted a significant difference for operative time $(F(2,134)=6.10, p=$ $0.0029)$. A Tukey post-hoc test revealed that productivity was statistically significantly higher in the focal positive surgical margins group compared to the negative surgical margins group (42.0 \pm 15.6 minutes, $p$ $=0.021)$ and between the extensive positive margins group and the negative margins group $(53.7 \pm 22.1$ minutes, $p=0.043$ ).

Table 2

Operative and oncological outcomes of the patients who underwent partial nephrectomy between January 2014 and December 2019

\begin{tabular}{|c|c|c|c|c|c|}
\hline Variable & $\begin{array}{l}\text { Overall } \\
N= \\
137\end{array}$ & $\begin{array}{l}\text { Negative } \\
\text { surgical } \\
\text { margins } \\
\mathrm{N}=115\end{array}$ & $\begin{array}{l}\text { Extensive } \\
\text { positive surgical } \\
\text { margins } \\
\mathrm{N}=7\end{array}$ & $\begin{array}{l}\text { Focal positive } \\
\text { surgical } \\
\text { margins } \\
\mathrm{N}=15\end{array}$ & $\begin{array}{l}\mathrm{P} \\
\text { value }\end{array}$ \\
\hline Approach & & & & & 0.81 \\
\hline Open & $\begin{array}{l}37 \\
(27.0)\end{array}$ & $33(28.7)$ & $1(14.3)$ & $3(20.0)$ & \\
\hline Laparoscopic & $\begin{array}{l}25 \\
(18.3)\end{array}$ & $20(17.4)$ & $2(28.6)$ & $3(20.0)$ & \\
\hline Robotic & $\begin{array}{l}75 \\
(54.7)\end{array}$ & $62(53.9)$ & $4(57.1)$ & $9(60.0)$ & \\
\hline $\begin{array}{l}\text { Operative time in Minutes } \\
\text { (Standard Deviation) }\end{array}$ & $\begin{array}{l}235.8 \\
(58.8)\end{array}$ & $\begin{array}{l}228.5 \\
(52.8)\end{array}$ & $282.1(68.9)$ & $270.5(77.6)$ & $\begin{array}{l}<.01 \\
0.01\end{array}$ \\
\hline $\begin{array}{l}\text { Warm Ischemia Time in } \\
\text { Minutes (Standard } \\
\text { Deviation) }\end{array}$ & $\begin{array}{l}30.8 \\
(12.7)\end{array}$ & $29.8(12.6)$ & $39.0(10.6)$ & $34.9(13.5)$ & 0.10 \\
\hline $\begin{array}{l}\text { Estimated Blood loss in Ml } \\
\text { (Standard Deviation) }\end{array}$ & $\begin{array}{l}280.3 \\
(297.0)\end{array}$ & $\begin{array}{l}266.2 \\
(295.2)\end{array}$ & $498.1(395.0)$ & $284.7(234.9)$ & 0.14 \\
\hline $\begin{array}{l}\text { Length of Hospitalisation } \\
\text { Stay in Days (Standard } \\
\text { Deviation) }\end{array}$ & $\begin{array}{l}5.7 \\
(4.3)\end{array}$ & $5.7(4.6)$ & $6.1(3.2)$ & $4.8(2.0)$ & 0.70 \\
\hline $\begin{array}{l}\text { Clavien } 3 \text { and above } \\
\text { Complications }\end{array}$ & $\begin{array}{l}12 \\
(8.8)\end{array}$ & $11(9.6)$ & $0(0.0)$ & $1(6.7)$ & 0.65 \\
\hline Local Recurrence & $4(2.9)$ & $0(0.0)$ & $4(57.1)$ & $0(0.0)$ & $\dot{L}_{0.01}$ \\
\hline Metastasis & $3(2.2)$ & $1(0.9)$ & 2 (33.3) & $0(0.0)$ & $\begin{array}{l}< \\
0.01\end{array}$ \\
\hline
\end{tabular}

Pathological details of the nephrectomy specimens are provided in Table 3. 92.7\% of the tumour were PT1 in nature, and the remainder was pT3. 56.3\% were low grade based on the WHO/International Society of Urological Pathology classification, with $40.0 \%$ high grade and $3.7 \%$ which were not assigned a grading as they were chromophobe in histology. Of the 5 tumours were categorised as others, 2 were 
translocation renal cell carcinomas and 3 were recognised as unclassified after multi-disciplinary meetings with the uropathologists. There was no clinically significant association with the margins and the various pathological factors except for perinephric fat invasion $(p=0.01)$. 
Table 3

Pathological data of the patients who underwent partial nephrectomy between January 2014 and December 2019

\begin{tabular}{|c|c|c|c|c|c|}
\hline Variable & $\begin{array}{l}\text { Overall } \\
N= \\
137\end{array}$ & $\begin{array}{l}\text { Negative } \\
\text { surgical } \\
\text { margins } \\
\mathrm{N}=115\end{array}$ & $\begin{array}{l}\text { Extensive positive } \\
\text { surgical margins } \\
\mathrm{N}=7\end{array}$ & $\begin{array}{l}\text { Focal positive } \\
\text { surgical margins } \\
\mathrm{N}=15\end{array}$ & $\begin{array}{l}P \\
\text { value }\end{array}$ \\
\hline $\begin{array}{l}\text { Pathological } \\
\text { Stage, } \mathrm{n}(\%)\end{array}$ & & & & & 0.47 \\
\hline T1a & $\begin{array}{l}110 \\
(80.3)\end{array}$ & 94 (81.8) & $3(42.9)$ & $13(86.7)$ & \\
\hline T1b & $\begin{array}{l}17 \\
(12.4)\end{array}$ & 15 (13.0) & $1(14.3)$ & $1(6.7)$ & \\
\hline T2 & $0(0.0)$ & $0(0.0)$ & $0(0.0)$ & $0(0.0)$ & \\
\hline T3 & $\begin{array}{l}10 \\
(7.3)\end{array}$ & $6(5.2)$ & $3(42.9)$ & $1(6.7)$ & \\
\hline $\begin{array}{l}\text { ISUP/WHO } \\
\text { Grade }\end{array}$ & & & & & 0.74 \\
\hline $1-2$ & $\begin{array}{l}76 \\
(55.5)\end{array}$ & 65 (56.5) & 3 (42.9) & 8 (53.3) & \\
\hline $\begin{array}{l}3-4, \\
\text { Unclassified }\end{array}$ & $\begin{array}{l}61 \\
(44.5)\end{array}$ & $50(43.5)$ & $4(57.1)$ & $7(46.7)$ & \\
\hline Histology & & & & & 0.99 \\
\hline Clear cell & $\begin{array}{l}109 \\
(79.6)\end{array}$ & $91(79.1)$ & $4(57.1)$ & $14(93.3)$ & \\
\hline Papillary & $\begin{array}{l}16 \\
(11.6)\end{array}$ & $14(12.1)$ & $2(28.5)$ & $0(0.0)$ & \\
\hline Chromophobe & $6(4.4)$ & $5(4.4)$ & $0(0.0)$ & $1(6.7)$ & \\
\hline Others & $6(4.4)$ & $5(4.4)$ & $1(14.3)$ & $0(0.0)$ & \\
\hline $\begin{array}{l}\text { Perinephric Fat } \\
\text { Invasion }\end{array}$ & & & & & $\begin{array}{l}< \\
0.01\end{array}$ \\
\hline No & $\begin{array}{l}126 \\
(92.0)\end{array}$ & 109 (94.8) & $4(57.1)$ & $13(86.7)$ & \\
\hline Yes & $\begin{array}{l}11 \\
(8.0)\end{array}$ & $6(5.2)$ & $3(42.9)$ & $3(13.3)$ & \\
\hline $\begin{array}{l}\text { Renal Sinus } \\
\text { Invasion }\end{array}$ & & & & & 0.30 \\
\hline
\end{tabular}




\begin{tabular}{|c|c|c|c|c|c|}
\hline Variable & $\begin{array}{l}\text { Overall } \\
N= \\
137\end{array}$ & $\begin{array}{l}\text { Negative } \\
\text { surgical } \\
\text { margins } \\
\mathrm{N}=115\end{array}$ & $\begin{array}{l}\text { Extensive positive } \\
\text { surgical margins } \\
\mathrm{N}=7\end{array}$ & $\begin{array}{l}\text { Focal positive } \\
\text { surgical margins } \\
\mathrm{N}=15\end{array}$ & $\begin{array}{l}\mathrm{P} \\
\text { value }\end{array}$ \\
\hline No & $\begin{array}{l}135 \\
(98.5)\end{array}$ & $114(99.1)$ & $6(85.7)$ & $15(100.0)$ & \\
\hline Yes & $2(1.5)$ & $1(0.9)$ & $1(14.3)$ & $0(0.0)$ & \\
\hline Necrosis & & & & & 0.37 \\
\hline No & $\begin{array}{l}123 \\
(89.8)\end{array}$ & $102(88.7)$ & $6(100.0)$ & 15 (93.8) & \\
\hline Yes & $\begin{array}{l}14 \\
(10.2)\end{array}$ & $13(11.3)$ & $0(0.0)$ & $1(6.2)$ & \\
\hline Sarcomatoid & & & & & 0.16 \\
\hline No & $\begin{array}{l}136 \\
(99.3)\end{array}$ & $115(100.0)$ & $7(100.0)$ & $14(93.3)$ & \\
\hline Yes & $1(0.7)$ & $0(0.0$ & $0(0.0)$ & $1(6.7)$ & \\
\hline
\end{tabular}

4 (2.9\%) had a local recurrence and $3(2.2 \%)$ had metastases. There were 4 deaths, 2 of which died of causes directly attributable to renal cell carcinoma, 2 of which died from unrelated causes of metastatic colorectal carcinoma and ischemic heart disease. Using local recurrence as an endpoint, the Kaplan Meier survival at 3 years was 1.0 for the patients with negative margins and focal positive surgical margins and 0.5 for the patients with extensive positive margins (Fig. 1). Using metastases as an endpoint, the Kaplan Meier survival at 2 years was 0.99 for negative margins, 1.00 for focal positive margins, and 0.67 for extensive positive margins (Fig. 2). Median time to local recurrence and metastasis was 19.2 months and 26.5 months respectively.

\section{Discussion}

To date, there has been a myriad of studies that evaluate the present of positive surgical margins after partial nephrectomy. However, there is significant heterogeneity in the population of the involved margins and to our knowledge, there are limited studies to evaluate the clinical significance of the extent of the positive margins. Although retrospective studies ${ }^{3,4}$ report lower surgical margins rates, our PSM rate of $16.1 \%$ is comparable to contemporary prospective studies such as the the RECORd $2^{5}$ project, comprising of a PSM rate of $16.5 \%$ in 2076 patients. Significantly, this study differentiated that focal PSM in partial nephrectomy likely has the same implications on local recurrence as negative surgical margins.

Bensalah et al found that recurrence-free, cancer-specific, and overall survival were similar for PSM and NSM patients for both matched and unmatched cohorts ${ }^{6}$. Hence, they concluded that PSM does not seem to influence cancer-specific survival. However, there were limitations to the multivariable model 
generated to arrive at this conclusion, which included a lack of consideration of the characteristics of the PSM such as size, number, location and multifocality. Our study cohort found a clear prognostic difference between focal and extensive PSM. There was no association was found between the presence of focal PSMs and local recurrence risk. However, extensive PSM was associated with reduced local recurrence-free survival and metastasis-free survival. Hence, the question remains if early treatment in the form of radical nephrectomy or focal ablation may be beneficial for patients with extensive PSM.

With the introduction of robot-assisted laparoscopic surgery in 2014, there was a concordant fall in the number of open and laparoscopic partial nephrectomies performed within our institution. Tabayoyong et $\mathrm{al}^{7}$ reported that the robotic approach significantly predicted for higher PSM rates compared to open partial nephrectomies in 11587 patients from the National Cancer Database, with an odds ratio of 1.79, which remained at 1.73 after stratification by hospital types. While our study did not find any statistical difference amongst the group, it appears that there is a much higher prevalence of focal PSM amongst the robotic approach compared to the open approach. The likely reason for this is that increasing confidence with the robotic and enucleation approach has enabled tumours of greater complexity to be tackled including hilar and endophytic tumours, which involves closer dissection margins to the tumour pseudocapsule.

Amongst the multiple clinical parameters that we investigated, male gender and perinephric fat invasion were the main factors that were significantly associated with positive margins, in particular the group with extensive PSM. This observation is in line with previous studies carried out by other investigators. Bansal et al ${ }^{8}$ found similar associations within the Canadian Kidney Cancer information system database found that pathological stage of T3 and above and a high Fuhrman grade were risk factors for PSM on multivariable analyses. Ani et al ${ }^{9}$ also report associations of stage and fat invasion with PSM. The male gender has been shown to have a greater likelihood of adherent perinephric fat and a higher Mayo adhesive probability score ${ }^{10}$. Taken together, these findings suggest that the presence of fat invasion, which may prove to be a challenge to discern pre-operatively on imaging and intraoperatively, resulting in PSMs.

The current study is limited by its retrospective nature and small cohort size, which could influence conclusions due to limited statistical power. Other limitations include the lack of definition of tumour grading at the site of the positive margin and further characterisation of the location of the PSM. In addition, most of the cases were localised T1 tumours, thus extrapolations to high risk partial nephrectomies done for imperative reasons should be caveated. However, this report represents a significant series with adequate follow-up from a tertiary referral centre supported by experienced uropathologists who were able to perform extensive assessments.

Ultimately, one of the pertinent clinical decisions to make for patients with PSMs following partial nephrectomies is to distinguish those who need adjuvant therapy from those for whom active surveillance would prove the more prudent option. This study provides further clarification on the broad umbrella term of positive surgical margins for patient counselling, follow up and selection for treatment. 
This lays the foundation for future studies to be performed on prospective cohorts to elucidate the clinical significance of PSM in the management of localised renal cell carcinoma.

\section{Conclusion}

PSM and focal PSM share similar peri-operative associations with significantly prolonged operative time in male patients when compared with NSM but have different pathological and oncological implications to each other. The higher association of perinephric fat involvement with extensive PSM may account for the finding that local recurrences exclusively occur in PSM. While it remains to be seen what the best treatment is for patients with PSMs, our data may provide beneficial information regarding how to best risk stratify patients and determine the timeline for the choice of any adjuvant therapy.

\section{Declarations}

\section{Ethics approval and consent to participate:}

All experimental protocols were approved by the Domain Specific Review Board of the National Healthcare group, Singapore with the study reference number 2016/01304. Informed consent was waived by Domain Specific Review Board of the National Healthcare group. All methods were carried out in accordance with relevant guidelines and regulations.

\section{Consent for publication:}

All the authors fully consent for publication.

\section{Availability of data and materials:}

The datasets used and/or analysed during the current study available from the corresponding author on reasonable request.

\section{Competing interests:}

There are no competing interests.

\section{Funding :}

No funding was required for this study to be carried out.

\section{Authors' contributions:}


WZT and THY wrote the main manuscript text and LKY prepared data analysis. All authors reviewed the manuscript

\section{Acknowledgements:}

There are no acknowledgements.

\section{Authors' Information:}

Nil

\section{References}

1. Padala SA, Barsouk A, Thandra KC, et al. Epidemiology of Renal Cell Carcinoma. World J Oncol. 2020;11(3):79-87.

2. Van Poppel H, Da Pozzo L, Albrecht W, et al. A prospective randomized EORTC intergroup phase 3 study comparing the complications of elective nephron-sparing surgery and radical nephrectomy for low-stage renal cell carcinoma. Eur Urol. 2007;51(6):1606-15.

3. Marszalek M, Carini M, Chlosta P, et al. Positive surgical margins after nephron-sparing surgery. Eur Urol. 2012;61(4):757-63.

4. Tellini R, Antonelli A, Tardanico R, et al. Positive Surgical Margins Predict Progression-free Survival After Nephron-sparing Surgery for Renal Cell Carcinoma: Results From a Single Center Cohort of 459 Cases With a Minimum Follow-up of 5 Years. Clin Genitourin Cancer. 2019;17(1):e26-e31.

5. Schiavina R, Mari A, Bianchi L, et al. Predicting positive surgical margins in partial nephrectomy: $A$ prospective multicentre observational study (the RECORd 2 project). Eur J Surg Oncol. 2020;46(7):1353-9.

6. Bensalah K, Pantuck AJ, Rioux-Leclercq N, et al. Positive surgical margin appears to have negligible impact on survival of renal cell carcinomas treated by nephron-sparing surgery. Eur Urol. 2010;57(3):466-71.

7. Tabayoyong W, Abouassaly R, Kiechle JE, et al. Variation in Surgical Margin Status by Surgical Approach among Patients Undergoing Partial Nephrectomy for Small Renal Masses. J Urol. 2015;194(6):1548-53.

8. Bansal RK, Tanguay S, Finelli A, et al. Positive surgical margins during partial nephrectomy for renal cell carcinoma: Results from Canadian Kidney Cancer information system (CKCis) collaborative. Can Urol Assoc J. 2017;11(6):182-7.

9. Ani I, Finelli A, Alibhai SM, et al. Prevalence and impact on survival of positive surgical margins in partial nephrectomy for renal cell carcinoma: a population-based study. BJU Int. 2013;111(8):E300-5. 
10. Davidiuk AJ, Parker AS, Thomas CS, et al. Mayo adhesive probability score: an accurate image-based scoring system to predict adherent perinephric fat in partial nephrectomy. Eur Urol. 2014;66(6):116571.

\section{Figures}

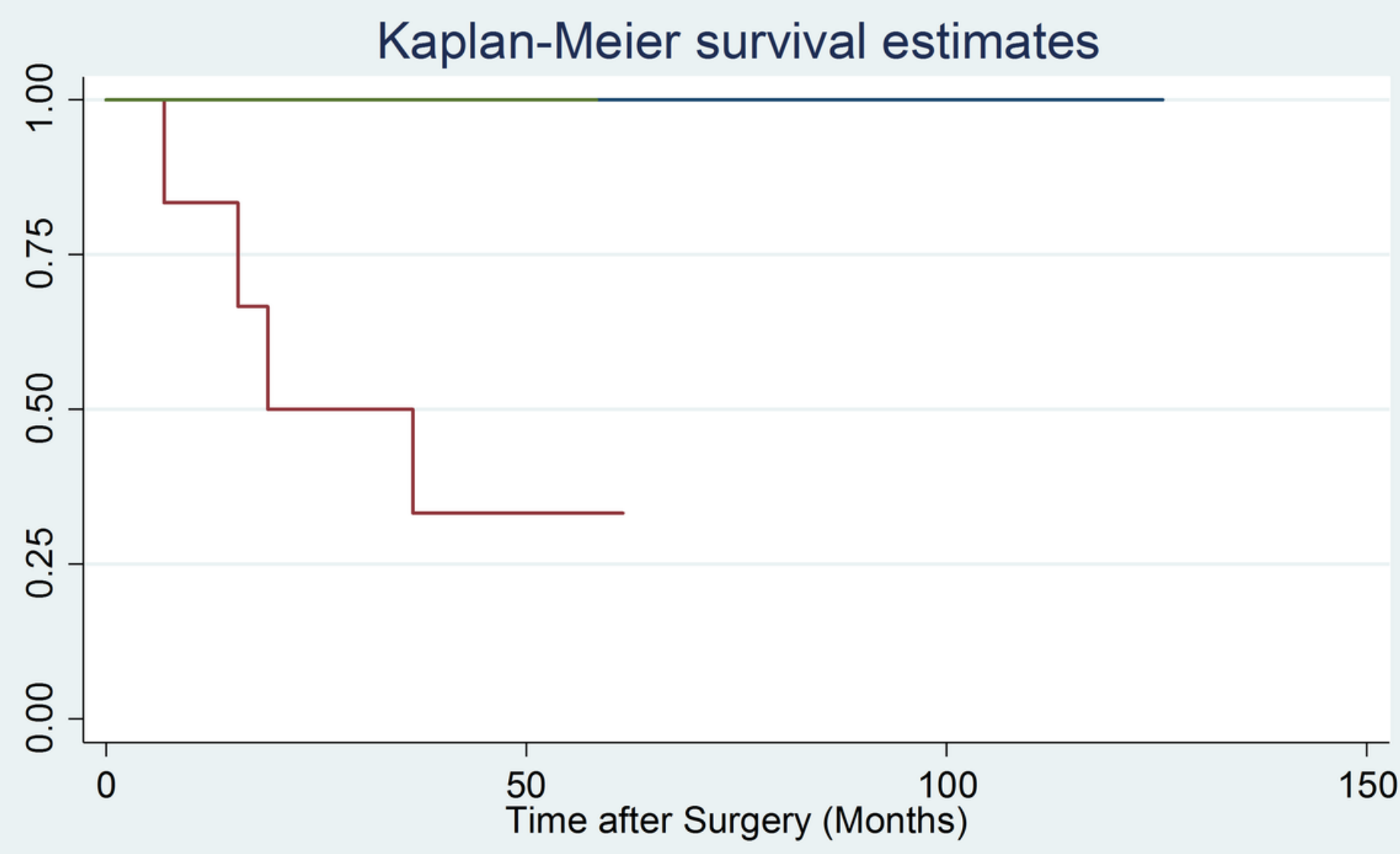

Figure 1

Kaplan-Meier curve depicting local recurrence-free survival, stratified according to margins features 


\section{Kaplan-Meier survival estimates}

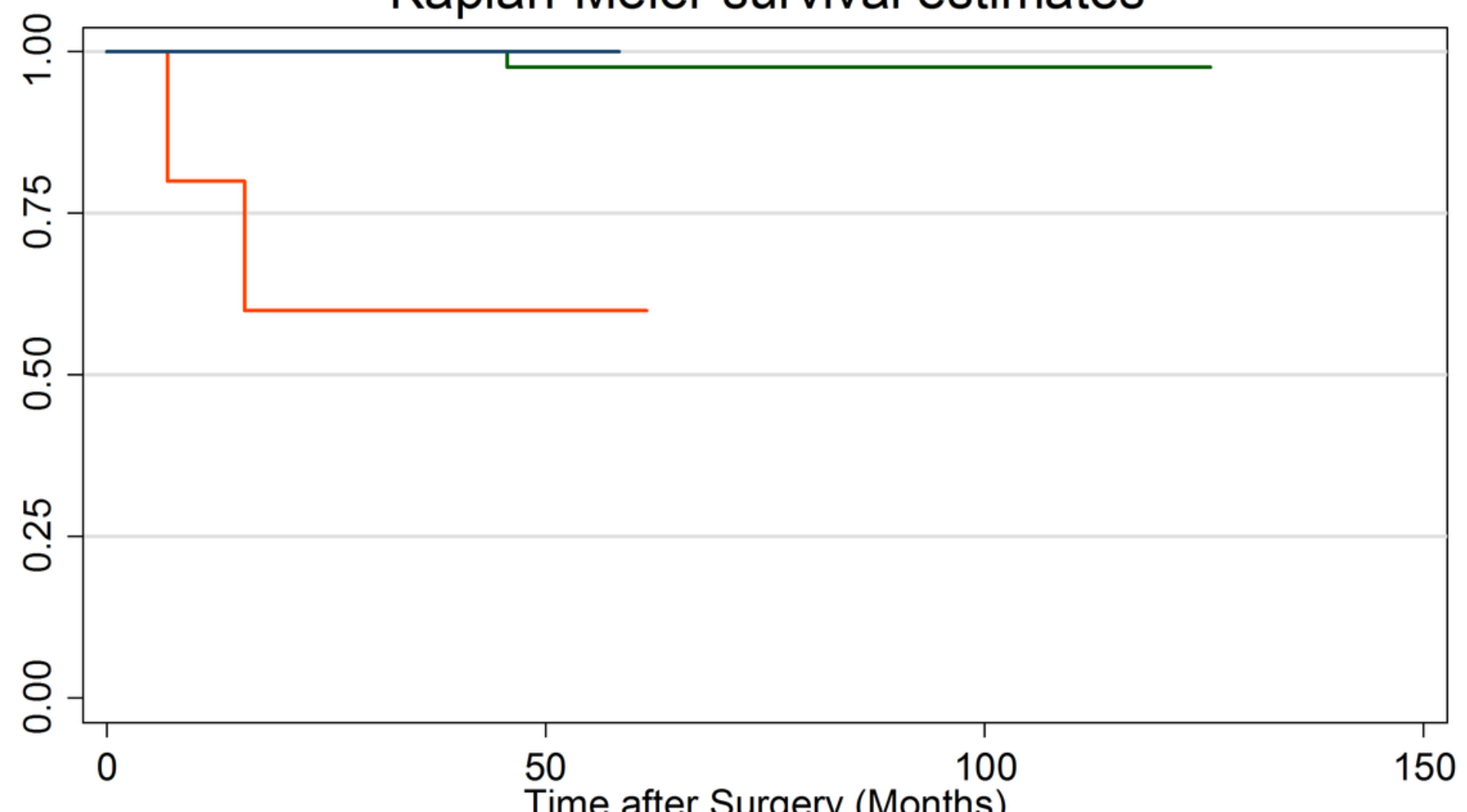

Negative Margins Extensive Positive Margins Focal Positive Margins

Figure 2

Kaplan-Meier curve depicting metastasis-free survival, stratified according to margins features.

\section{Supplementary Files}

This is a list of supplementary files associated with this preprint. Click to download.

- PNx1204.xlsx 